\title{
Adventure Sports Development Paradigm
}

\author{
Chalak Majidi \\ (Assistant Professor, Kharazmi University) \\ Marjan Saffari \\ (Assistant Professor, Tarbiat Modares University) \\ Alireza Elahi \\ (Associate Professor, Kharazmi University) \\ Mohammad Khabiri \\ (Associate professor, University of Tehran)
}

\begin{abstract}
:
In recent years, adventure sports have been growing increasingly. Adventure sports are new and appealing activities that regularly include some kinds of physical and mental challenges and the relative presence of the natural environment. These activities are presenting new paths and sometimes they called a serious competitor for mainstream sport. The aim of this study was to present a paradigm for adventure sports development. The qualitative methodology used in this study has followed an interpretive approach that was achieved by grounded theory. Data was collected from literature, interviews, focus groups, adventure sports-related documentary films, and movies. The results of this study are presenting an adventure sports paradigm. In this paradigm developmental causal conditions of adventure sports, a contexture of adventure sports, existing intervening conditions, and contextual conditions, strategies and tactics for developing adventure sports and finally consequences. To appropriate recognition and encountering with this field, that most probably will be one of the main parts of sport, we suggest doing more scientific research, especially with futurology approaches.
\end{abstract}

Keywords: Paradigm, Adventure Sports, Qualitative research, Grounded Theory 
Adventure sports development pattern (2017), Ch. Majidi, M, Saffari, Alireza Elahi, Mohammad Khabiri. Research in Sport Management \& Motor Behavior, In Press.

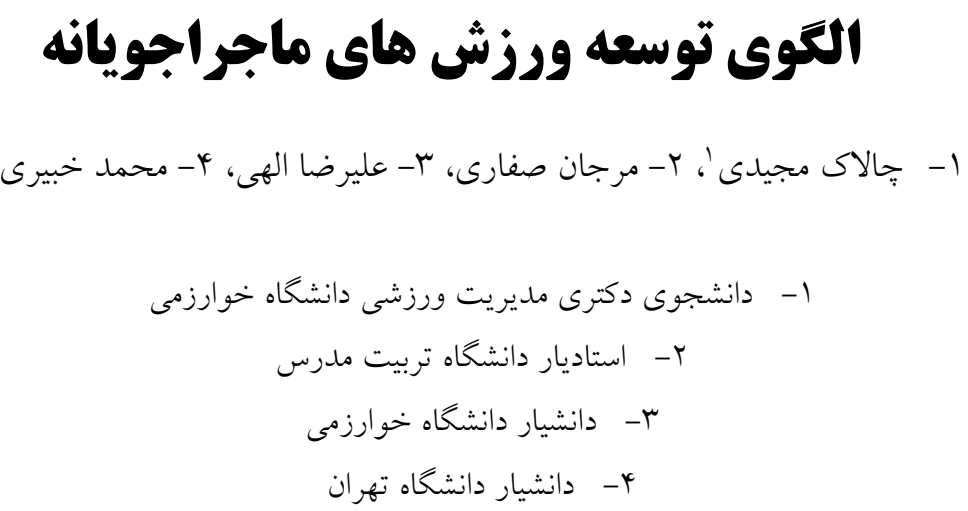

\section{جكيده}

در سالهاى اخير ورزشهاى ماجر اجويانه سريعاً در حال رشد بوده است. ورزشهاى ماجر اجويانه فعاليتهايى جديد و جذاب و بهطور معمول شامل ميزانى از حالشهاى فيزيكى و ذهنى و حضور نسبى مولفه طبيعت

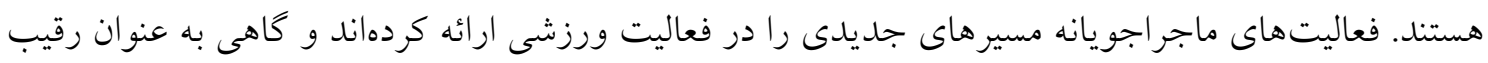

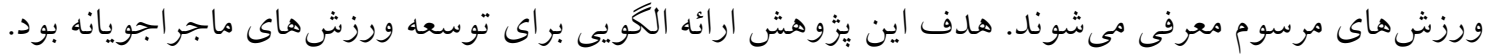

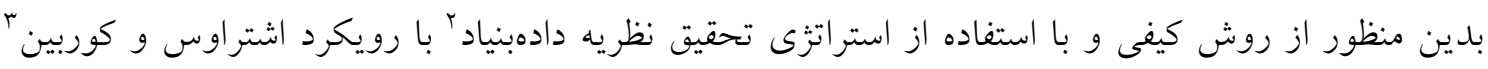

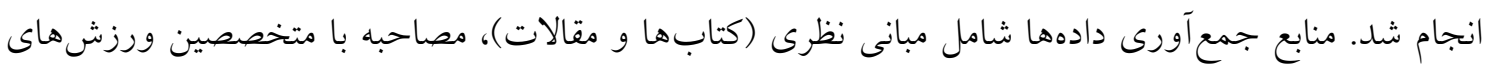

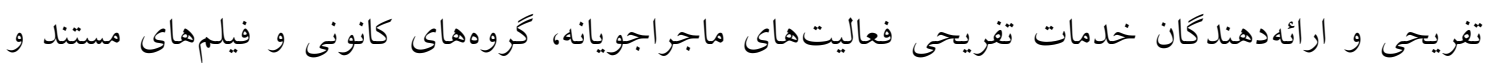

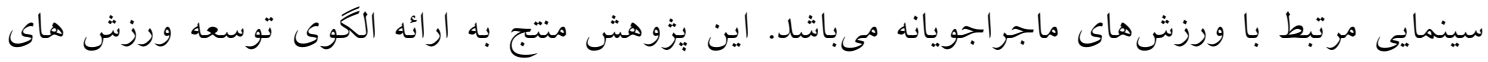

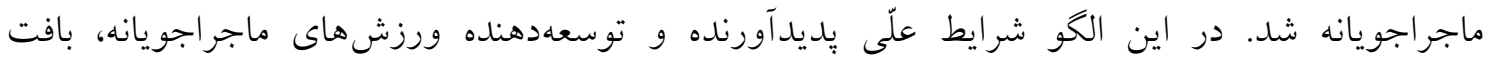

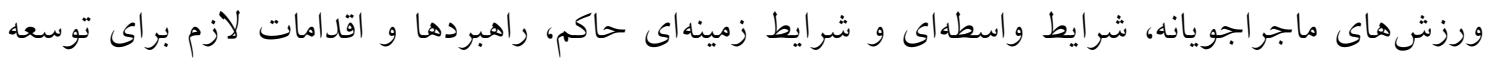

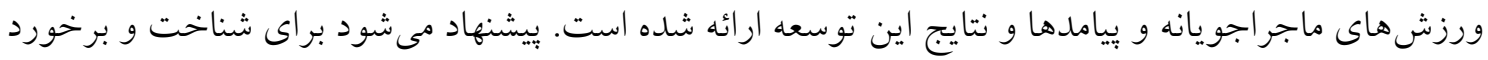

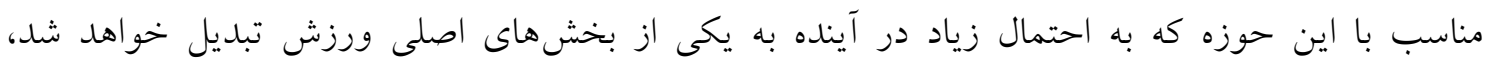

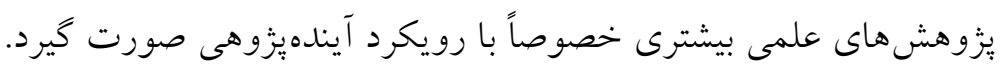

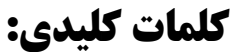

الكو، ورزشهاى ماجراجويانه، تحقيق كيفى، نظريه داده بنياد

\footnotetext{
${ }^{1}$ Chalakm@ymail.com, .91^^v.0.r

${ }^{2}$ Grounded theory

${ }^{3}$ Strauss \& Corbin
} 
Adventure sports development pattern (2017), Ch. Majidi, M, Saffari, Alireza Elahi, Mohammad Khabiri. Research in Sport Management \& Motor Behavior, In Press.

\section{مقام}

امروزه ديخر ورزشهاى رقابتى رايجترين بخش مشاركت در ورزش نيستند. شيوههاى ديخر ورزش مانند ورزش تفريحى، آمادكى جسمانى و ورزشهاى بىنهايت و ماجراجويانه به صورت قابل توجهى توسعه يافته، محبوبيت يافته و تبديل به اشكال جايخزين ورزش شده است (1). يكى از تحولات عظيم جهانى، رشد سريع در ورزش هاى ماجراجويانه بوده است (Y). از سال •19V افزايش خشم گيرى در انواع مختلف ورزشهاى ماجراجويانه صورت گرفت (T)، اما آغاز هزاره سوم منادى انفجار محبوبيت ورزشهاى ماجراجويانه بوده است، ورزش هايى كه كاهاً ورزشهاى سبك زندگى و يا ورزشهاى جايخزين ناميده مى شوند. فعاليتهاى

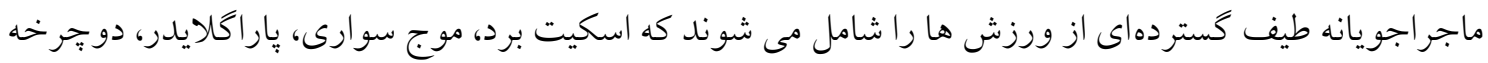
سوارى دانهيل، طبيعت كردى و قايقرانى آب هاى خروشان از اين جمله هستند. اين ورزش ها راههاى جديد و جالشالشاى بالقوهاى را براى روشهاى سنتى مفهوم سازى و عملى ورزش ارائه مى كنند (أل، ه، 9). ورزشهاى ماجر اجويانه جيزهايى مانند احساسات و هيجانات قوى و خطر (ريسك) را در خود دارند كه به ندرت مىتوان در ورزشهاى ديخر يافت (r). در خصوص اين كه بايد اين فعاليتها را جهه ناميد تا تجربه مشاركت را به درستى تشريح كند، تعاريف و بحث هاى بسيارى توسط محققين، صاحب نظران و اصحاب رسانه صورت گرفته است. براى مثال ويتن (...

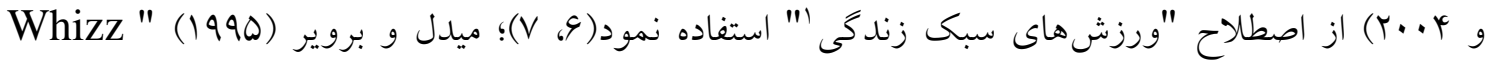

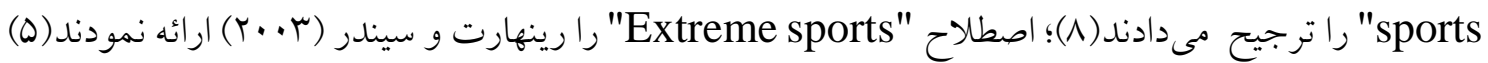

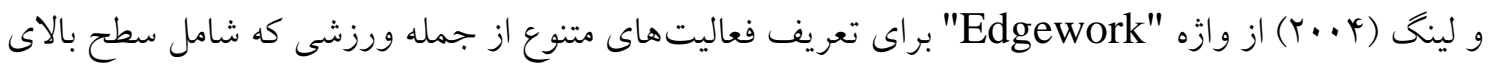
خطر هستند، استفاده كرد(9)، جايى كه از مرزها و هنجارها مى گذرند. مفاهيم ديخرى نيز جهون "ورزشهاى خطر ناك ז"، "ورزشهاى ترسناك" "، "ورزشهاى جايكز ين / متفاوت †"و يا "ورزشهاى جديده" مورد استفاده قرار كرفته است (• (1). تمايل موجود به ورزشهاى ماجراجويانه، به هرحال، نشانه تغيير طرز تفكر و نيازهاى برآورده شده توسط ورزش در دنياى مدرن است (11). ورزش هاى ماجراجويانه همانطور كه ويتن (Y......) و

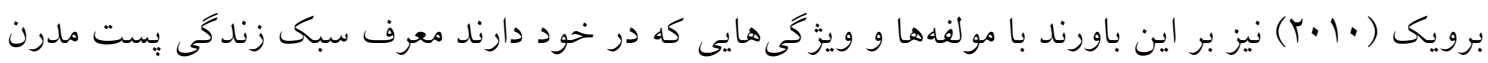
هستند(r، 9). در راستاى همين باور برويك (•(Y) بيان مىكند كه ايده مشاركت در اين فعاليتها لذت، لذت كرايى، دركيرى، خود شكوفايى، جريان، زندگى در لحظه، هجوم آدرنالين و ساير پاداشهاى درونى را

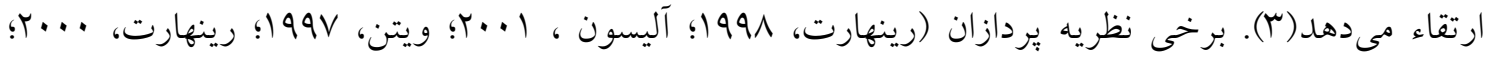

\footnotetext{
${ }^{1}$ Lifestyle Sports

${ }^{2}$ Dangerous Sports

${ }^{3}$ Panic Sports

${ }^{4}$ Alternative Sports

${ }^{5}$ New Sports
} 
Adventure sports development pattern (2017), Ch. Majidi, M, Saffari, Alireza Elahi, Mohammad Khabiri. Research in Sport Management \& Motor Behavior, In Press.

استدمن، 1997) بيان كرداند كه بيدايش اين فعاليتهاى ورزشى و خرده فرهنگ و سبك زندگى هاى گسترش يافته در كنار آنها را به عنوان مرحلهاى از توسعه ورزش در نظر كرفته اند و برخى از اين صاحب نظران به صورت "يست مدرن" آنها را توصيف مى كنند (4). به طور خلاصه مى توان ورزشهاى ماجر اجويانه را اينخونه معرفى كرد، فعاليتهايى هستند جديد و جذاب و به طور معمول شامل ميزانى از جالش هاى فيزيكى و ذهنى و حضور نسبى مولفه طبيعت كه مسيرهاى جديدى را در فعاليت ورزشى ارائه كردهاند و كاهاً به عنوان رقيب ورزش هاى مرسوم در جوامع معرفى مىشوند. تلاش اين ورزشها براى تجربه زندكى به سبك شخصى و به جالش كشيدن توانايىهاى فرد در مقابل خود انسان، طبيعت و محيط مىباشد. از ديدكاه تكاملى اخر به مساله

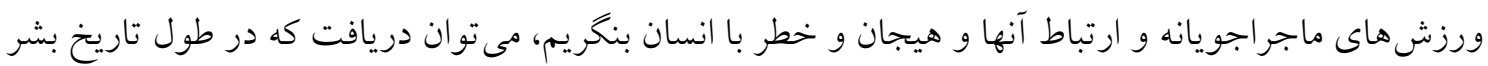
و حضور بشر در بازى بقاء در طبيعت و جابه جايى به دليلهاى مختلف و جالشهاى طبيعى همواره درگير جالش و ريسك بوده است. از اين رو سبك زندگى مدرن به طور قطع با كمبود جالش و هيجانات سبك زندگى كذشته مواجه مىباشد. به نوعى مىتوان كفت اين خواست خطر و هيجان در دنياى مدرن جستجوى مولفه

هاى سبك زندگى كذشته مىباشد (r).

به هرحال با توجه به اينكه ورزشهاى ماجراجويانه نوظهور هستند، به همين جهت در مورد آنها و مشاركت كنند كان در آنها (ورزشكار و مربى) اطلاعات محدودى وجود دارد (r) (I). مى توان مشاهده كرد كه در ييشنهادات

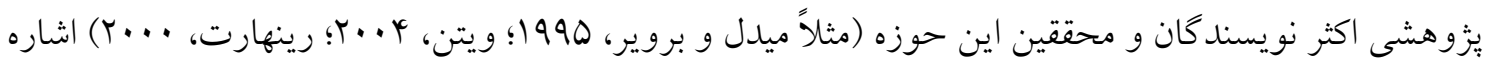
به لزوم تحقيقات بيشتر براى شناخت بهتر و كاملتر اشاره مىشود. از اين رو همانطور كه با مطالعه دقيق در هر يديدهاى مى توان دريافت كه آن پِديده فقط محدود به خود نمى باشد و متاثر از و موثر بر متغيرهاى متعدد فردى و اجتماعى مى باشد، ساده انگارانه خواهد بود اكر فكر كنيم فعاليت در ورزشهاى ماجراجويانه صرفاً خود فعاليت و نه بيشتر از آن است (با). از طرفى در ايران مطالعات علمى در حوزه ورزش هاى ماجراجويانه بسيار اندى و محدود به حوزه گردشخرى بوده است و جوابخوى نياز اطلاعاتى موجود نمى باشد. سازمان هاى متولى ورزش، اوقات فراغت و سلامت و همجنين صاحبان كسب و كار در زمينه ورزش و كردشخرى در سالهاى آينده براى مواجهه مناسب و استفاده از مزايا و بيشخيرى از آسيب هاى احتمالى اين حوزه نيازمند اطلاعاتى جامع خواهند بود كه يُوهشهايى از اين دست ميتواند تامين كننده اين نيازها باشد. به هر حال با بال توجه به رشد روزافزون اين فعاليتها و عدم وجود اطلاعات كافى در خصوص جّكونكى مشاركت در اين حوزه و يا ارائه عكس العمل مناسب نسبت به شرايط متفاوت اين حوزه نياز به مطالعه بيشتر در اين زمينه

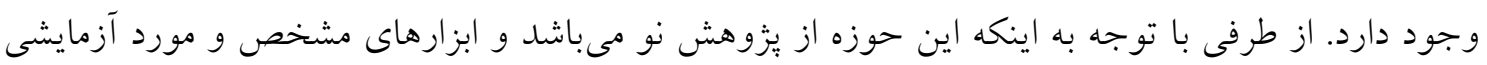
جهت مطالعه اين يديده يافت نشد، روش تحقيق كيفى كزينه مناسبى براى مطالعه اين حوزه مىباشد. با توجه

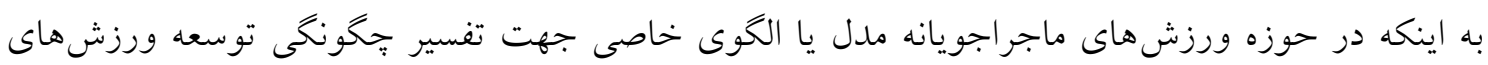


Adventure sports development pattern (2017), Ch. Majidi, M, Saffari, Alireza Elahi, Mohammad Khabiri. Research in Sport Management \& Motor Behavior, In Press.

ماجراجويانه ارائه نشده است، اين يزوهش سعى دارد تا با كمك رويكرد يارادايمى اشتراوس -كوربين الخويى براى توسعه ورزشهاى ماجراجويانه را ارائه دهد. اين رويكرد از اين رو انتخاب شد كه منابع انسانى مطلّع و

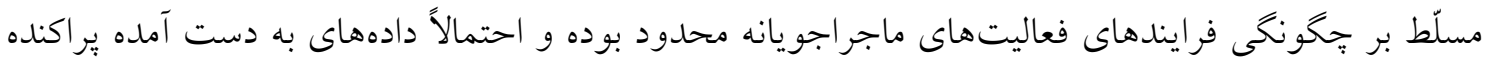
و غير منسجم مى شد از اين رو با توجه به اينكه اين رويكرد با ارائه شش محدودهه براى تفسير دادهها امكان تدوين مدلى منسجم را فراهم مىنمود براى انجام كار مورد استفاده قرار گرفت. همجنين اين تحقيق مىتواند يشي زمينه اى براى تحقيقات آينده در حوزه ورزشهاى ماجر اجويانه و يلى براى شناخت بهتر اين بديده باشد.

\section{روش شناسى}

اين يُوهش از نظر ماهيّت و اهداف، يزوهشى كيفى و با استفاده از استراتزى تحقيق نظريه داده بنياد' با رويكرد اشتراوس و كوربين 'انجام شده است. نظريه داده بنياد عبارت است آنجه كه از مطالعه نظام مند داده ها مستخرج و تجزيه و تحليل مى شود. در اين شيوه جمع آورى داده، تجزيه و تحليل و نظريه محتمل در يك رابطه نزديك با هم قرار مى گيرند († | (1). آنجه در روش تئورى سازى داده بنياد مهم است دستيابى به دادههاى زرف است كه بتو اند الكوها، مفاهيم، طبقات و ويزَّى ها و ابعاد بديده را تبيين نمايد (ه) (1). با استفاده از اين روش يزّوهشكر

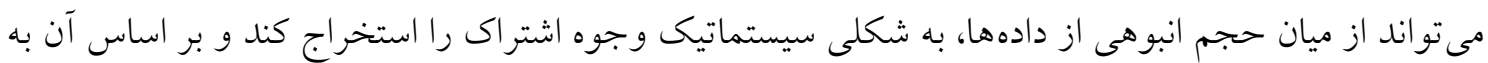
تئورى بردازى در حوزه بزوهشى خود ببردازد.

با توجه به اينكه اين حوزه از ورزش جه در بخش عملياتى و جهه در حوزه يزوهش جديد مىباشد و محققين متخصص در اين زمينه يافت نشد، بنابراين براى جمع آورى داده ها به جهت محدود بودن منابع با رويكرد

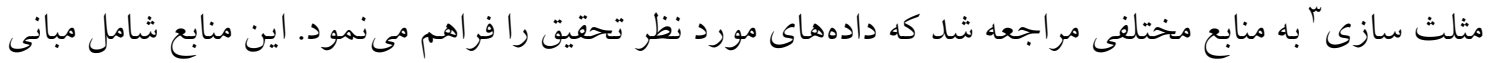
نظرى (كتاب ها و مقالات)، مصاحبه با متخصصين ورزشهاى تفريحى و ارائه دهندكان خدمات تفريحى فعاليتهاى ماجر اجويانه، كروههاى كانونى (ورزشكاران ورزشهاى ماجر اجويانه) و فيلمهاى مستند و سينمايى مرتبط با ورزش هاى ماجر اجويانه مىباشد.

تجزيه و تحليل دادههاى به دست آمده از منابع نيز در سه مرحله انجام گرديد. در مرحله اول كدگذارى باز از طريق بررسى مبانى نظرى، مصاحبههاى ضبط شده با فعالين يزوهشى و عملياتى و گروههاى كانونى، فيلمهاى مستند و سينمايى مورد كد گذارى مكتوب قرار كرفت. در مجموع سوץ كد اوليه (يس از حذف كدهاى تكرارى)

\footnotetext{
${ }^{1}$ Grounded theory

${ }^{2}$ Strauss \& Corbin

${ }^{3}$ Triangulation
} 
Adventure sports development pattern (2017), Ch. Majidi, M, Saffari, Alireza Elahi, Mohammad Khabiri. Research in Sport Management \& Motor Behavior, In Press.

به دست آمد. در مرحله بعد با ارتباط برقرار نمودن بين كدهاى به دست آمده در مرحله اول بازنويسى شدند و از اين طريق دستهايى از كدهاى مشابه شكل گرفت و تعداد ال كد محورى توليد شد. در مرحله آخر كدهاى محورى به دست آمده در كدگذارى انتخابى در قالب سازههاى الكوى بارادايمى (شرايط علّى، بديده اصلى، شر ايط زمينهاى، شر ايط واسطهاى، راهبردها و ييامدها) گروه بندى و ارتباط نظاممندى برقرار گرديد.

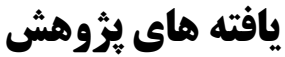

دادههاى به دست آمده از منابع مختلف مورد استفاده در اين تحقيق در سه مرحله كدكذارى باز، محورى و انتخابى در قالب كدهاى باز، مفاهيم و مقوله ها دسته بندى شدند. جداول زير مفاهيم و مقوله هاى به دست آمده را كزارش مى نمايد.

جدول (. مقولههاى استخراج شده از مفاهيم (عوامل علّى)

\begin{tabular}{|c|c|}
\hline مقوله & مفهوم \\
\hline \multirow{3}{*}{ 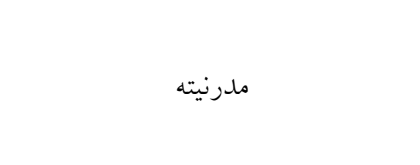 } & تحولات جامعه و مدرنيته \\
\hline & انسان مدرن \\
\hline & ورزش مدرنيته \\
\hline \multirow{2}{*}{ رشد سرمايه دارى و اهميت فردخرايى } & سرمايهدارى مولّد صنعت اوقات فراغت \\
\hline & اهميت فرد در عصر جديد \\
\hline \multirow{2}{*}{ خواست هيجان در جوامع بدون هيجان } & نيازهاى ارضاء نشده انسان در عصر جديد \\
\hline & خواست ذاتى بشر براى تجربه هيجان و يسك \\
\hline كاهش تعامل زندكى انسان با طبيعت & مشاركت بيشتر در محيطهاى طبيعى \\
\hline يتانسيل جغرافيايى & وجود يتانسيل جغرافيايى براى فعاليتهاى ماجراجويانه \\
\hline \multirow{2}{*}{ تمايل به تمايز } & تلاش براى شناخته شدن به عنوان طبقه مرفه \\
\hline & علاقه انسان به تمايز در اجتماع \\
\hline يتانسيل موجود مشاركت & يتانسيل روانى اجتماعى \\
\hline
\end{tabular}

جدول r. مقولههاى استخراج شده از مفاهيم (شرايط زمينهاى)

\begin{tabular}{|c|c|}
\hline 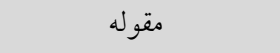 & 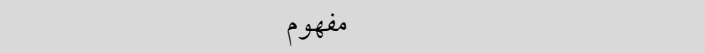 \\
\hline 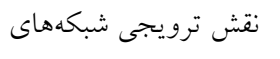 & تاثير شبكههاى اجتماعى در ترويج و شناخته شدن فعاليتهاى \\
\hline اجتماعى & ماجراجويانه \\
\hline \multirow{3}{*}{ سياستهاى سازمانها } & نياز به هماهنگى سازمانهاى دستاندر كار ورزش و تفريحات \\
\hline & مشخص كردن خط مشى ويزه سازمانهاى متولى ورزش و اوقات \\
\hline & فراغت \\
\hline \multirow{2}{*}{ رشاجر كردشخرى } & افزايش اهميت فعاليتهاى اوقات فراغت \\
\hline & افزايش مشاركت كردشخُى ماجر اجويانه \\
\hline
\end{tabular}


Adventure sports development pattern (2017), Ch. Majidi, M, Saffari, Alireza Elahi, Mohammad Khabiri. Research in Sport Management \& Motor Behavior, In Press.

جدول س. مقوله هاى استخراج شده از مفاهيم (يديده اصلى (بافت ورزش هاى ماجر اجويانه))

\begin{tabular}{|c|c|}
\hline 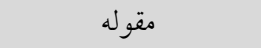 & 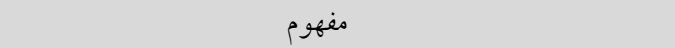 \\
\hline جالش با طبيعت & دركيرى انسان با طبيعت به طرق و دلايل مختلف \\
\hline 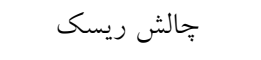 & حضور مولفه ريسك (در سطوح متفاوت) و اهميت جالش با آن \\
\hline \multirow{2}{*}{ مشاركت كنتد كان } & مشاركت اقشار مختلف و متفاوت \\
\hline & تنوع در مشاركت \\
\hline \multirow{2}{*}{ 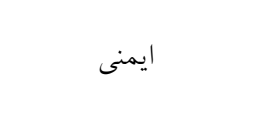 } & اهميت علم و تكنولوزى در ايمنى و طراحى ابزار \\
\hline & يذيرش خطر با آكاهى از مسايل ايمنى \\
\hline \multirow{2}{*}{ فرهنگ و سبك زندگى } & بروز خرده فرهنگ متمايز \\
\hline & سبك زندگى لذت كرايانه و فرد محور \\
\hline 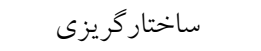 & عدم وجود ساختار و تمايل براى عبور از مرزها و محدوديتها \\
\hline 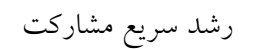 & رشد سريع با نرخ بالا \\
\hline
\end{tabular}

جدول عا. مقولههاى استخراج شده از مفاهيم (شرايط واسطهاى)

\begin{tabular}{|c|c|}
\hline 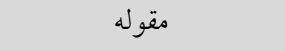 & مفهوم \\
\hline ي بيشرفت فن آورى & نقش تسهيل كندكى تكنولوزى در مشاركت \\
\hline \multirow{2}{*}{ 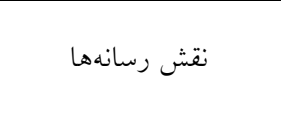 } & حضور رسانهاى در حال افزايش \\
\hline & نقش تبليغات رسانه اى در شناخته شدن فعاليتهاى ماجر اجويانه \\
\hline \multirow{4}{*}{ شاخت فعاليتهاى } & كمبود حمايت به دليل عدم شناخت \\
\hline & كمبود منابع دانشى جهت ارائه اطلاعات مسئولين، فعالين و عموم \\
\hline & اصلاح برداشتهاى نادرست \\
\hline & نا آشنا بودن عموم با فرصتهاى مشاركت \\
\hline \multirow{2}{*}{ مسايل مالى و ادارى تهيه } & كمبود يا نبود اماكن و تجهيزات مناسب و به روز \\
\hline & دشوارى در تهيه تجهيزات \\
\hline 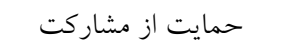 & تشويق و حمايت از مشاركت در فعاليتهاى ماجر اجويانه \\
\hline حاميان مالى & اهميت حضور حمايت متناسب مالى \\
\hline
\end{tabular}

جدول ه. مقولههاى استخراج شده از مفاهيم (راهبردها)

\begin{tabular}{|c|c|}
\hline 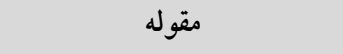 & 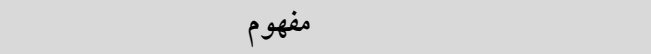 \\
\hline \multirow{5}{*}{ فراهم سازى زيرساختها } & ايجاد و تسهيل دسترسى امكانات سخت افزارى \\
\hline & ايجاد زير ساخت ها و تسهيل دسترسى به آنها \\
\hline & حمايت سازمان ها با رويكرد سرمايه گذارى \\
\hline & 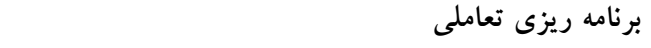 \\
\hline & بومى سازى برخى فعاليتها \\
\hline \multirow{2}{*}{ افزايش و تسهيل حمايت مالى } & تسهيل و تشويق حضور حاميان مالى در اين حوزه \\
\hline & حمايت مالى سازمانهاى متولى ورزش در راستاى توسعه \\
\hline & اطلاع رسانى و افزايش شناخت جامعه نسبت به اين حوزه \\
\hline
\end{tabular}


Adventure sports development pattern (2017), Ch. Majidi, M, Saffari, Alireza Elahi, Mohammad Khabiri. Research in Sport Management \& Motor Behavior, In Press.

\begin{tabular}{|c|c|}
\hline \multirow{2}{*}{ فرهنخ يرورى و ارتقاى } & افزايش مطالعات علمى و ارتقاى دانش \\
\hline & شناساندن سبك زندگى، ويزّكى ها و مزاياى مشاركت \\
\hline \multirow{4}{*}{ همايش ها و مسابقات جشنوارهها، } & تسهيل زمينه برگزارى همايش و جشنواره \\
\hline & تسهيل برغزارى رويدادهاى رقابتى \\
\hline & رقابت عامل ايجاد جذابيت و انكيزه مشاركت \\
\hline & رقابت حرفهاى (مزاياى اقتصادى و ترويجى) \\
\hline ايجاد و آموزش ايمنى & شناخت، معرفى و ايجاد ايمنى در محيط مشاركت \\
\hline \multirow{2}{*}{ برند سازى و ترويج رسانهاى } & برند سازى و نمايش جذابيتهاى فعاليتها \\
\hline & ير رنغتر كردن حضور رسانهاى \\
\hline \multirow{2}{*}{ 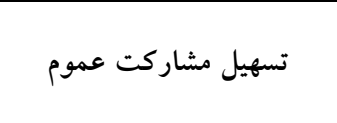 } & تسهيل مشاركت عمومى \\
\hline & اولويت با همخانى نمودن \\
\hline
\end{tabular}

\begin{tabular}{|c|c|}
\hline 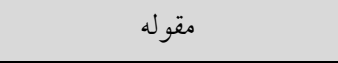 & مفهوم \\
\hline توسعه كردشخرى ماجر اجويانه & كمى به توسعه كردشكرى ماجر اجويانه و جذب كردشخران \\
\hline 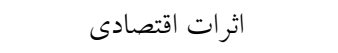 & تاثيرات در اقتصاد خرد و كلان \\
\hline \multirow{3}{*}{ آثار فرهنگ -اجتماعى } & كمك به تغيير و ارتقاى سطح مشاركت در فعاليتهاى \\
\hline & ورزشى \\
\hline & رتقاء سلامت اجتماعى و سبك زندگى اجتماعى \\
\hline \multirow{2}{*}{ شكل كيرى ساختارها } & تلاش جهت ساختار دهى و ايجاد مسابقات و رويدادها \\
\hline & مقاومت در برابر ساختار \\
\hline احتمال بسيار بالاى رشد و & توسعه و رشد غير قابل انكار مشاركت در آينده \\
\hline \multirow{2}{*}{ كمكى به جامعه براى رسيدن به } & تفاوت تمايلات مشاركت ورزشى \\
\hline & هميت توجه به خواسته هاى متفاوت اقشار مختلف \\
\hline \multirow[t]{2}{*}{ ايجاد و كسترش تجارت هاى } & كردشخرى و ....) هرعه شاى ارائه دهنده خدمات (آموزشى، تمرينى، \\
\hline & توسعه تجارت هاى مرتبط \\
\hline \multirow{3}{*}{ غاجر اجويانه در دنياى ورزش فعاليتهاى } & ل ظهور فعاليتهاى جديد \\
\hline & تغيير ورزشهاى مرسوم \\
\hline & ت ت توان رقابت با ورزش هاى مرسوم \\
\hline
\end{tabular}

شرايط علّى: شرايط و عواملى هستند كه باعث بروز غير قابل اجتناب مشاركت در ورزشهاى ماجراجويانه در جامعه مى شوند. در واقع منظور از شرايط علّى، رويدادها يا اتفاقاتى است كه بر اين بِيديده تاثير خذاشته و

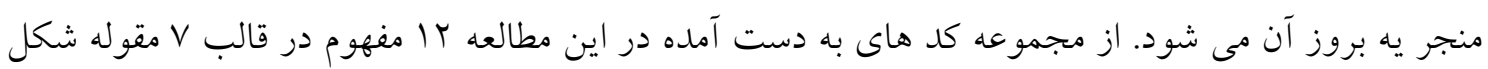
كرفتند كه به شرح زير مى باشند: 
Adventure sports development pattern (2017), Ch. Majidi, M, Saffari, Alireza Elahi, Mohammad Khabiri. Research in Sport Management \& Motor Behavior, In Press.

1- مدرنيته: جهانى شدن و ارتباطات سريع نيز به نوبه خود باعث گسترش و سريع آن در سطح دنيا شده است. ييشرفت دانش بشر و تكنولوزى در كنار زمان موسوم به فراغت باعث بروز تلاش انسان مدرن براى تجربه كونهاى جديدى از فعاليتهاى ورزشى و تفريحى شده است. r- رشد سرمايهدارى و اهميت فردگرايى: اين بستر از طرفى باعث گسترش فعاليتهاى ماجراجويانه و تنوع آنها مى شود و از طرفى براى كسب منافع مالى در تلاش براى مالكيت بر آنهاست كه جالشى نيز براى اين حوزه محسوب مى شود.

r- خواست هيجان در جوامع بدون هيجان: درحاليكه الياس و دانينگ ا (91911) ورزش را "جويش هيجان

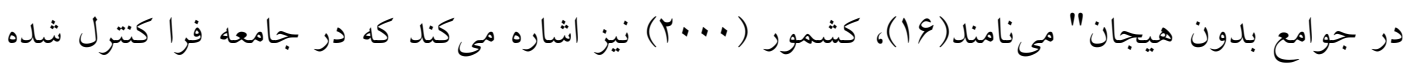
مدرن ارضاء نيازهاى عميق انسان سخت است، از اين رو ورزش اهميت بيدا مى كند(IV). به نظر مىرسد ورزشهاى ماجراجويانه به خوبى مى توان ياسخكوى ارضاى نيازهاى مسكوت انسان مدرن باشد. انسانى كه در طول تاريخ در محيط خود جالشها و خطراتى داشته است اما زندگى امن امروزى خالى از اين جالشها بوده و باعث بروز احساس كمبود هيجان در زندگى انسان شده است كه انسان به طرق مختلف

$$
\text { رسمى و غير رسمى به دنبال تجربه آن مىباشد. }
$$

ץ- كاهش تعامل زندگى انسان با طبيعت: از ديدگاه تكاملى نيز اخر به مساله ورزشهئ رهاى ماجراجويانه و ارتباط آنها و هيجان و خطر با انسان بنخريم، مى توان دريافت كه بشر در طول تاريخ به دليل حضور در بازى بقاء در طبيعت و جابه جايى به دلايل مختلف و جالشهاى طبيعى همواره درگير تجالش و ريسك بوده است. در كذر زمان ويزگى هاى روانشناختى و فيزيولوزيكى براى بقاء با شرايط ساز كار شده است و اين در حالى است كه در دنياى امن مدرن جالشهاى كذشته وجود ندارد اما ويز كى هاى ساز كار يافته كماكان در انسان وجود دارد. ه- يُّانسل جغر افيايى: با توجه به تنوع فعاليتهاى ماجر اجويانه شرايط جغر افيايى متفاوتى براى هر كدام نياز است كه در كشورى جون ايران با اقليم هاى گوناگون و داشتن كوه، دريا، جنگل، رودخانه و دشت شرايط به كونهاى است كه موقعيت براى فعاليتهاى بسيارى فراهم است 9- تمايل به تمايز: انسان در جامعه مدرن به دنبال كلاس و تمايز اجتماعى است و اين مساله ابتداً در بر برسي طبقات بالاى جامعه و به وسيله مالكيت كالاها و يا يرداختن به فعاليتهاى متمايز صورت مى كيرد. از طرفى طبقات بايين جامعه تلاش مى كنند تا با ٍِرداختن به فعاليتهاى مشابه مرفهين، خود را نزديك به آنها معرفى كنند. از اين رو و با توجه به اينكه تماشاى فعاليتهاى ماجر اجويانه تحسين و حسرت

\footnotetext{
${ }^{1}$ Elias \& Dunning
} 
Adventure sports development pattern (2017), Ch. Majidi, M, Saffari, Alireza Elahi, Mohammad Khabiri. Research in Sport Management \& Motor Behavior, In Press.

را در تماشاگر ايجاد مى كند، اين تبديل به انخيزهاى براى مشاركت در فعاليتهاى مشابه و حتى با شدت و استاندارد بالاتر مى شود.

V- يتانسيل موجود مشاركت: هيجانطلبى در ميان درصدى' از افراد شدت بالاترى دارد و تعداد افرادى كه داراى خصوصيات روانى اجتماعى هم راستا با فعاليتهاى ماجراجويانه هستند، در برخى جوامع بيشتر است.

بافت ورزشهاى ماجر اجويانه (يديده اصلى) : يديده اصلى مورد بررسى در اين مطالعه مىباشد و عبارت از بافت فعاليتهاى ورزشى ماجراجويانه مىباشد. سازه مربوط به اين بديده در الخوى اين مطالعه، از • ل مفهوم شكل گرفته از كدهاى به دست آمده در قالب V مقوله اصلى شكل گرفت. كه در زير خزارش مىشوند.

1- جالش با طبيعت: انسان در گذر از تاريخ همواره مغلوب و مجذوب قدرت طبيعت و بوده و در تلاش براى غلبه بر آن و يا الهام گرفتن از آن براى كسب خواسته هايش بوده است و اين جالش هميشكى، براى انسان مدرن با وجود دانش و تكنولوزى هاى در دسترس خود جذابيت دو جندانى ييدا كرده است. اين مساله در ورزش هاى ماجراجويانه به صورت استفاده از تجهيزات با تكنولوزى سطح بالا با الهام از طبيعت براى انجام فعاليتهاى فراتر از توان معمول بشر و همجنين تلاش براى غلبه به قله ها و سقف هاى توانايى طبيعت بروز بيدا كرده است. r- جالش ريسك r: مولفه ريسك جزء جدانشدنى از ورزش هاى ماجر اجويانه است و شايد يكى از دلايل اصلى متفاوت بودن از ورزشهاى مرسوم نيز باشد. اما تعريف اين ريسك و محدودههاى آن به وضوح روشن نبوده و نسبى مى باشد و بستخى به متغيرهاى گوناگونى دارد كه مانند ميزان مهارت و شايستكى فرد در انجام مهارتهاى لازم در فعاليت، ريسك موجود در فعاليت و هم:جنين ميزان ادراك فرد از اين دو، كه مىتواند ناشى از دانش و تجارب قبلى فرد باشد. جستجو گران هيجان سطح بالا و ورزشكاران با تجربههاى ماجراجويانه قبلى، خطر را در سطح بايينترى نسبت به ديخران ادراك مى كنند و به همين جهت در يك تجربه برابر بيش بينى اضطراب كمترى هم خواهند داشت و اين

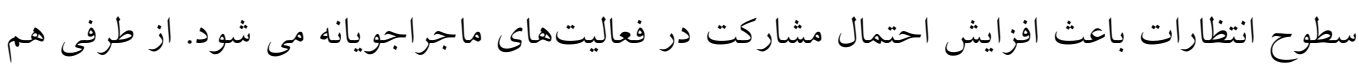
به واسطه اينكه ساير افراد جامعه كه اين فعاليتها را از نزديك لمس نكرده اند، به دليل نداشتن ادراك كامل و صحيح، نخرشهاى گاهاً نادرستى نسبت به افراد ماجر اجو و فعاليتهاى ماجر اجويانه دارند. 
Adventure sports development pattern (2017), Ch. Majidi, M, Saffari, Alireza Elahi, Mohammad Khabiri. Research in Sport Management \& Motor Behavior, In Press.

ז- مشار كت كنندگًان: ميزان ريسك موجود در فعاليتهاى ماجر اجويانه و همجنين منطقه امن' تعريف شده هر فرد براى خود مى تواند تعيين كننده ميزان جسارت لازم براى شركت در اين فعاليتها باشد. تنوع موجود در فعاليتها باعث ايجاد تنوع در مشاركت كنندگان نيز شده و از اقشار و گروه هاى مختلف اجتماعى مشاركت دارند. آغازكر اين فعاليتها در جوامع طيف روشنفكر جوان طبقه متوسط هستند. مشاركت كندكان شامل افراد فعالين مداوم، تماشاكران و افرادى كه به جهت تمايل به تعلق به خرده فرهنخ گروه فعالين و يا دلايل ديخر اين فعاليتها به صورت موردى و يا متناوب مشاركت مى كنند و همجنين يتانسيل مشاركت در ساير اقشار جامعه نيز وجود دارد. مثلاً اقشارى با انحيزه آموزشى به صورت آموزش از طريق فعاليتهاى ماجر اجويانه به جهت ياديرى و بهبود مهارت هاى فردى و اجتماعى و يا درمانى براى افرادى كه ناهنجارى يا نقصان برخى ويزگى هاى فردى اجتماعى برى برى را دارند.

†- ايمنى: علم و تكنولوزى در ايمنى و طراحى ابزار كه با وجود ييشرفتهايى كه در اين حوزه اتفاق افتاده باعث شده است تا ابزارهاى ايمن تر طراحى شده و فعاليتها داراى امنيت و ايمنى بيشترى باشند. با توجه به اينكه ريسك يكى از اصلى ترين مولفه هاى فعاليتهاى ماجر اجويانه است. مسئله آسيبهاى احتمالى از اهميت بالايى برخوردار است از اين رو بروز حوادثى در اين حوزه از فعاليتهاى ورزشى از نظر تماشاگران اين فعاليتها ممكن است برجستهتر و با اغراق ديده شود در صورتى كه ميزان آسيبهاى تجربههاى ماجراجويى نسبت به بسيارى است فعاليتهاى ديخر كمتر مىباشد. ه- فرهنگ و سبك زندگى: در ميان مشاركت كنند ان خرده فرهنگ هايى شكل مى گيرد كه از طرفى باعث تمايز ورزشكاران از ورزشهاى مرسوم حتى در ورزشهاى رسمى شده مانند اسنوبرد شده و

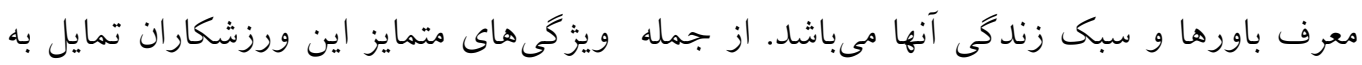

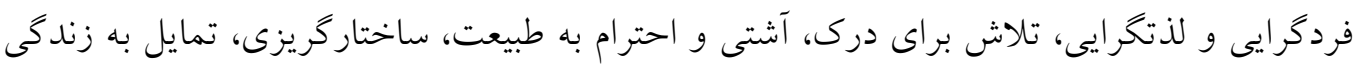
به سبك دلخواه شخصى، ريسك يذيرى و تمايل به تجربه ناشناخته ها مىتوان اشاره كرد. از ديخر جهت به دليل جذابيت بالا تمايل ديخران به حضور در ياتوق هاى شكل گرفته و اين خرده فرهنگ و تجربه سبك زندكى انخيزهاى براى مشاركت در اين فعاليتها مى شود. ييشروان و بنيانخذاران رشتههاى ماجراجويانه و ورزشكاران نخبه و در مواردى حاميان مالى اين ورزشها نقش قابل توجهى در شكل گيرى اين خرده فرهنگ ها دارند.

\footnotetext{
${ }^{1}$ Comfort zone
} 
Adventure sports development pattern (2017), Ch. Majidi, M, Saffari, Alireza Elahi, Mohammad Khabiri. Research in Sport Management \& Motor Behavior, In Press.

9- ساختارگريزى: نا محدود بودن مرز فعاليتهاى ماجراجويانه و تمايل شكستن ركوردها و عبور از سقف توانيى هاى انسان و صعود بر قله هاى قدرت طبيعت به نحوى باعث شده است تا ساختار خريزى و عدم تمايل براى قراركيرى تحت نظر قوانين و قواعد مشخص و يكسان، به يكى از شاخصترين

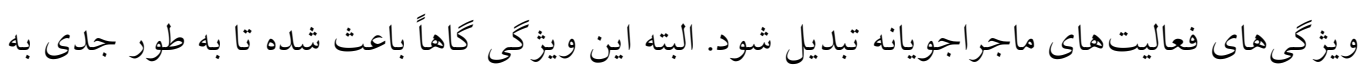
رسميت شناخته نشوند و به اندازه ساير حوزهها از حمايت برخوردار نشوند و حتى در مواردى غير قانونى شناخته شوند. V- رشد سريع مشاركت: به دليل ويزگى هاى متفاوت و جذابيت نو بودن و كمك رسانهاى تصويرى و در سالهاى اخير فضاى مجازى، فعاليتهاى ماجراجويانه رشد بسيار سريعى را تجربه كرده است كه در بيشتر كشورها از نرخ رشد ورزشهاى مرسوم (مثلا بيسبال در آمريكا) بيشى كرفته است. دليل ديخر اين رشد قارجى و بدون برنامه نبود استانداردها و شيوههاى مشخص انجام فعاليت و همجنين قابليت يادگيرى و آموزش غير حضورى مىباشد. وجود خرده فرهنگ هاى متمايز كه در بالا از آن سخن رفت نيز خود مشاركت افراد در فعاليتهاى ماجراجويانه نقش ترويجى و افزايش دهنده مشاركت را داراست.

شرايط زمينهاى: اين شر ايط شامل عوامل محيطى موجود كه با مشاركت در ورزشهاى ماجراجويانه در ارتباط هستند. سازه مربوط به شر ايط در اين مطالعه، از ه مفهوم شكل گرفته از كدهاى به دست آمده در قالب م مقوله اصلى شكل گرفت كه به شرح زير است:

ا. نش ترويجى شبكه هاى اجتماعى: امروزه اينترنت ابزارى سهل الوصول محيطى مناسب براى به اشتراى كذارى تجربه هاى ماجراجويانه مشاركت كنندكان فراهم نموده است. هم:جنين براى ارائه دهند كان خدمات در زمينه ورزشهاى ماجراجويانه، به عنوان كانال ترويجى ارزان و اثربخش نقش عمدهاى ايفا مى كند. همجنين برخى صاحبان تجارت نيز با حمايت مالى از مشاركت كنندكانى كه تعداد دنبال كننده بالايى دارند به تبليغات از طريق اين فعاليتها مى بردازند. نقش سياستهاى سازمانها: سازمانهاى متولى ورزش و سلامت كشور به عنوان فراهم كننده زيرساختها و تسهيل تهيه تجهيزات لازم جهت يرداختن به فعاليتهاى ماجراجويانه مىباشد. از

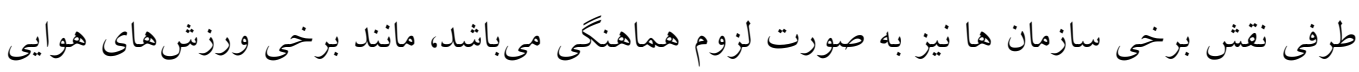

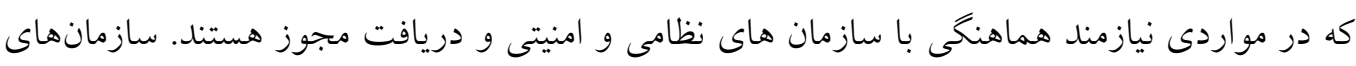
آموزشى نيز؛ به عنوان تربيت كننده افرادى كه در فعاليتهاى ماجر اجويانه مشاركت فعال مى كنند و 
Adventure sports development pattern (2017), Ch. Majidi, M, Saffari, Alireza Elahi, Mohammad Khabiri. Research in Sport Management \& Motor Behavior, In Press.

هم به عنوان استفاده كننده از فعاليتهاى ماجراجويانه به صورتى زمينه (مضمون / ابزارى) براى آموزش مهارتهاى فردى و اجتماعى مطرح هستند.

r. رشد گردشگرى ماجراجويانه: كردشكرى نيز يكى از فعاليتهاى مورد توجه حوزه اوقات فراغت است كه نقش قابل توجهى نيز بر اقتصاد كشور ها دارد و رشد روز افزونى را تجربه مىكند. در سالهاى اخير تجارب ماجراجويانه بخش قابل ملاحظهاى از گردشخرى (هَّ٪ انخيزههاى مشاركت

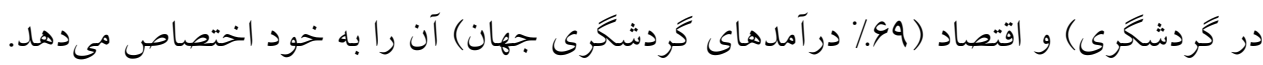

عوامل واسطهاى: عواملى كه به صورت تسهيل كننده و يا محدود كننده بر توسعه ورزشهاى ماجراجويانه موثر هستند. سازه مربوط به عوامل واسطهاى، از 11 مفهوم شكل كرفته از كدهاى به دست آمده در قالب 9 مقوله اصلى شكل كرفت. ا. يشرفت فن آورى: نقش تسهيل كننده تكنولوزى در مشاركت در فعاليتهاى ماجراجويانه به دو صورت قابل مشاهده است. دستهاى فن آورى هايى هستند كه باعث تغيير، تسهيل و يا يديد آمدن فعاليتهاى ماجراجويانه مى شوند و دسته ديخر فن آورى هايى كه در ارزان شدن، تسهيل دسترسى و افزايش ايمنى فعاليتهاى ماجر اجويانه نقش ايفا مى كنند. r. نقش رسانها: جذابيت رسانهاى به واسطه توجه به جنبه زيبايىشناسانه حركات در فعاليتهاى ماجر اجويانه بالا مىباشد و اين باعث شده است رسانها به بخش اين فعاليتها براى جذب مخاطب و همجنين زمينهاى براى تبليغات محصولات و خدمات از طريق آنها توجه نمايند. به نظر مىرسد ديد گاهى كاركردگرايانه بر برنامههاى رسانهاى اين فعاليتها حاكم است. r. شناخت فعاليتهاى ماجراجويانه: كمبود منابع دانشى در دسترس براى مسئولين، فعالين و عموم به واسطه كمبود فعاليتهاى دانشگاهى در اين حوزه باعث به ايجاد شرايطى مىشود كه عدم آكَاهىها باعث برداشتهاى نادرست از جگحونخى اين فعاليتها و مسايل حاكم بر آنها مىشود. اين نآشنايى و يا برداشت نادرست مىتواند باعث شود كه عموم مردم با فرصتهاى مشاركت آشنا نشوند و همجنين حاميان مالى از مزاياى حمايت از آنها مطلع نبوده و يتانسيل حمايت موجود بالفعل نخردد. f. مسايل مالى و ادارى تهيه امكانات: شيوه معاملات بين المللى ايران و آثار تحريمهاى اقتصادى و همجنين برخى قوانين گمركى باعث مى شود تا تهيه تجهيزات دشوار و گران گردد و اين عدم سهولت تهيه تجهيزات موجب ريزش بخش قابل توجهى از مشاركت كنندكان و صاحبان كسب و كار در فعاليتهاى ماجر اجويانه مى شود. 
Adventure sports development pattern (2017), Ch. Majidi, M, Saffari, Alireza Elahi, Mohammad Khabiri. Research in Sport Management \& Motor Behavior, In Press.

ه. حمايت از مشاركت: بررسى روندهاى موجود در فعاليتهاى ورزشى و آينده بزوهى مىتواند باعث آشنايى با آيندهاى محتمل و مزاياى آن شود. از اين رو با شناساندن مزاياى آيندههاى محتمل مطلوب مىتوان از فعاليتهاى آن حوزه حمايت نمود. 9. حاميان مالى: حضور حاميان مالى در كنار رويدادهاى ترويجى و رقابتى مىتواند منجر به نتيجه بردبرد گردد و البته تناسب ميان ويزگگىهاى محصولات يا خدمات حاميان مالى و فعاليت ماجر اجويانه مورد حمايت بر نتيجه حمايت براى هردو طرف تاثير كذار است.

راهبردها: اقداماتى كه موجب توسعه ورزش هاى ماجراجويانه خواهند شد. سازه مربوط به راهبردها، از 19 مفهوم شكل كرفته از كدهاى به دست آمده در قالب V مقوله اصلى شكل گرفت.

ا. فراهم سازى زير ساخت ها: سازمان هاى متولى ورزش، فرهنگ و سلامت جامعه بايد با رويكرد سرمايه كذارى از توسعه فعاليتهاى ماجراجويانه حمايت كنند و امكان دسترسى در مناطق مختلف كشور كه بتانسيل فعاليتهاى ماجراجويانه را دارا مىباشد را ايجاد و تسهيل نمايند. اين زيرساختها مى تواند علاوه بر ايجاد شرايط مناسب براى توسعه فعاليتها، به افزايش ايمنى و امنيت كمك كرده و نظارت و برنامهريزى را براى آينده آسانتر نمايد. اما نكته مهم اين است كه اين حمايت به واسطه تفاوت فرهنكى مشاركت كنند گان و ماهيت محيطى آنها بايد به صورت رفع موانع و فراهم نمودن زير ساختها شود و دخالتى در شيوههاى اجرا و يا تلاش در رسمى سازى صورت نخيرد و حمايت در عين حفظ استقلال صورت كيرد. از طرفى نيز با توجه به تنوع اقليمى و فرهنكى كشور تناسب

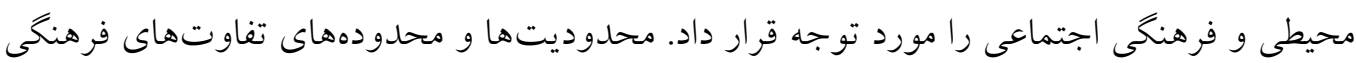
نيز مى تواند عاملى براى ايجاد تغييراتى در فعاليتها و بومى سازى آنها باشد. r. افزايش و تسهيل حمايت مالى: براى بخش خصوصى مسايلى جون انعطافيذير نمودن قوانين و مقررات، تشويقهاى مالياتى و يا ارائه امتيازاتى براى حاميان مالى را مىتوان مدنظر قرار داد. سازمانهاى دولتى هم در راستاى توسعه مشاركت ورزشى همه اقشار جامعه بايد در اين بخش هم حمايت مالى خود را اعمال نمايند.

r. فرهنگ برورى و ارتقاى شناخت: با ايجاد آكاهى از طريق رسانهاى علمى و عمومى مىتوان شناخت جامعه را نسبت به ورزش هاى ماجر اجويانه و بيامدهاى مشاركت در بخش هاى مختلف آن افزايش دادو سبك زندكى، ويزگى ها و مزاياى مشاركت را معرفى نمود. از طرفى نيز ورود اين ادبيات علمى به ادبيات مردم نقش قابل توجهى در توسعه اين فعاليتها خواهد داشت. 
Adventure sports development pattern (2017), Ch. Majidi, M, Saffari, Alireza Elahi, Mohammad Khabiri. Research in Sport Management \& Motor Behavior, In Press.

f. برگزارى جشنوارهها، همايشها و مسابقات: ايجاد زمينه برگزارى همايشهاو جشنو ارهها به صورت ويزه و يا ادوارى مىتواند در افزايش شناخت جامعه كمك كرده و براى مشاركت افراد ايجاد انكيزه كند و يُلهاى براى بركزارى رقابتهاى قهرمانى و حرفهاى باشد. رويدادهاى رقابت به دنبال خود افزايش مشاركت و حمايتهاى مالى و معنوى را خواهد داشت. ه. ارتقاء و آموزش ايمنى: بالا بردن ضريب امنيت و ايمنى از طريق آموزش و فراهم سازى تجهيزات استاندارد و همجنين تربيت منابع انسانى متخصص و البته آكاه سازى در خصوص مفهوم خطر و ايمنى در فعاليتهاى ماجر اجويانه مىتواند بسترى ايمن تر و جذابتر را براى مشاركت كنندكان فراهم آورد. 9. برند سازى و ترويج رسانهاى: بيشرفت و توسعه اين فعاليتهاى ورزشى نيازمند ديده شدن در جامعه است كه از طريق رسانهاى مختلف قابل دسترس مىباشد. با نشان دادن جنبههاى زيبايى شناختى و برجسته نمودن قهرمانها و سر آمدان رشتههاى مختلف ارتقاى وجهه اجتماعى اين فعاليتها مقدور خواهد شد.

V. تسهيل مشاركت عموم: خارج كردن وضعيت فعاليتهاى ماجر اجويانه از حالت انحصار به يك طبقه اجتماعى و يا فرهنكى مىتواند به طور قابل توجهى بر توسعه فعاليتهاى ماجر اجويانه و تسهيل ساير راهبردهاى مطرح شده كمك نمايد. ييامدها: اين سازه از الكو نتايج و بيامد هاى توسعه ورزشهاى ماجر اجويانه است كه از عا مفهوم شكل كرفته از كدهاى به دست آمده در قالب م مقوله اصلى تشكيل شده است.

1. توسعه گردشگرى ماجراجويانه: بخش عمدهاى از انخيزه مشاركت در فعاليتهاى كردشخرى و سهم بالايى از درآمدهاى گردشخرى مربوط به فعاليتهاى ماجراجويانه مىباشد. از اين رو افزايش توسعه فعاليتهاى ماجراجويانه به جذب گردشخر، كارآفرينى و اشتغالزايى در حوزه گردشكرى و توسعه كردشخرى ماجراجويانه كمى قابل توجهى خواهد نمود. r. اثرات اقتصادى: توسعه فعاليتهاى ورزشى ماجراجويانه تاثيراتى بر اقتصاد خرد و كلان خواهد كذاشت كه مىتوان از اين تاثيرات به مواردى از قبيل افزايش معاملات بين المللى، كارآفينى و ايجاد فرصت براى كسب و كارهاى بخش خصوصى، ايجاد بازار توليد و فروش تجهيزات و ارزآورى و ممانعت از خروج ارز را نام برد كه جّخونكى و ميزان اين تاثيرات خود نياز به مطالعه و بررسى دارد. r. آثار فرهنگى و اجتماعى: با توسعه ورزشهاى ماجراجويانه و افزايش مشاركت در آنها سطح سلامت جامعه و مشاركت در ورزش افزايش خواهد يافت كه افزايش نشاط اجتماعى را نتيجه خواهد داد. 
Adventure sports development pattern (2017), Ch. Majidi, M, Saffari, Alireza Elahi, Mohammad Khabiri. Research in Sport Management \& Motor Behavior, In Press.

يكى ديخر از مهمترين آثار اجتماعى توسعه فعاليتهاى ماجر اجويانه كاهش جرم و بزهكارى است، بدين صورت كه كانالى براى تخليه هيجانات فراهم مى كند f. شكل گيرى ساختار ها: رشد و توسعه باعث مىشود به مرور رقابتها و ركوردها و داورىها شكل بحيرد و قوانين رقابت ها و رويدادها تعيين گردد. سيستمى شدن اين فعاليتها نيز با خود بروكراسى و سلسله مراتب سازمانى را به همراه خواهد آورد. اما اين تناقض با ساختار گريز بودن اين فعاليتها خواهد داشت كه همواره جالشى بوده است براى ورزشكاران و فعاليت اين رشتهها كه باور دارند ساختارمند شدن باعث از بين رفتن ماهيت اصلى اين فعاليتها خواهد شد. ه. احتمال بسيار بالاى رشد و توسعه مشاركت: همانكونه كه از شكل گيرى فعاليتهاى ورزشى ماجراجويانه تا كنون ديده شده است اين فعاليتها با ورزشهاى مرسوم رقابت كردهاند و سرعت رشد مشاركت بالاترى از ورزشهاى مرسوم داشتهاند و اين روند كماكان ادامه خواهد داشت و در آينده به طور قطع يكى از روندهاى اصلى دنياى ورزش خواهند بود. צ. ايجاد و گسترش تجارت هاى مرتبط: افزايش محيطهاى ارائه خدمات آموزشى، تمرينى و تفريحى با توجه به كستره وسيع اين فعاليتها علاوه بر افزايش يتانسيل مشاركت به بتانسيل بالاى تجارتهاى مرتبط، نياز به توليدات و تجهيزات، را فراهم مى آورد. V. غالب شدن فعاليتهاى ماجراجويانه در دنياى ورزش: با توجه به تاثير گذارى رسانها و حاميان مالى بر روى توسعه روندهاى تغييرات و جذابيت بالاى فعاليتهاى ماجر اجويانه در بخش رسانهاى و همجنين زاينده بودن اين رشتها و بديد آمدن مداوم سبكها و رشتهاى مختلف؛ فعاليتهاى ماجر اجويانه توان رقابتى بالايى با ورزش هاى مرسوم دارند. كمك به جامعه براى رسيدن به دموكراسى بدنى: با توجه به تمايلات متفاوت شهروندان براى مشاركت ورزشى و اهميت توجه به خواسته هاى متفاوت آنها و رشد توجه انسان به امكان تمايز در جوامع مختلف؛ توجه به مفهوم دموكراسى بدنى در كنار ساير حقوق شهروندى در حال افزايش مىباشد. توسعه اين فعاليتها با توجه به تمايز و تنوع روشن آنها به رسيدن جوامع به دموكراسى بلدنى بسيار كمك خو اهد نمود.

در نهايت مرحله كد گذارى انتخابى كه مرحله اصلى نظريه يردازى مىباشد، بر اساس دو مرحله قبلى كدگذارى مقوله ها و روابط نظاممند آنها در يك جارجيوب واحد شكل كرفت. با كنار هم قرار دادن مقوله ها در يك ״ارجوب واحد و برقرارى ارتباط نظاممند آنها براى ارائه و شكل دادن به يك نظريه تنظيم مى شوند. يديده

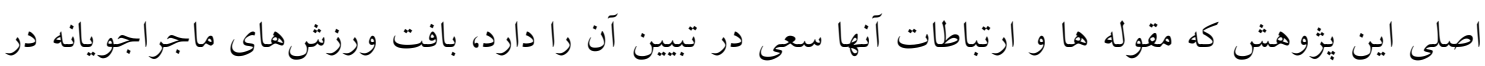
ايران است كه در زير الخوى حاصل از يافته هاى تحقيق ارائه شده است. 
Adventure sports development pattern (2017), Ch. Majidi, M, Saffari, Alireza Elahi, Mohammad Khabiri. Research in Sport Management \& Motor Behavior, In Press.

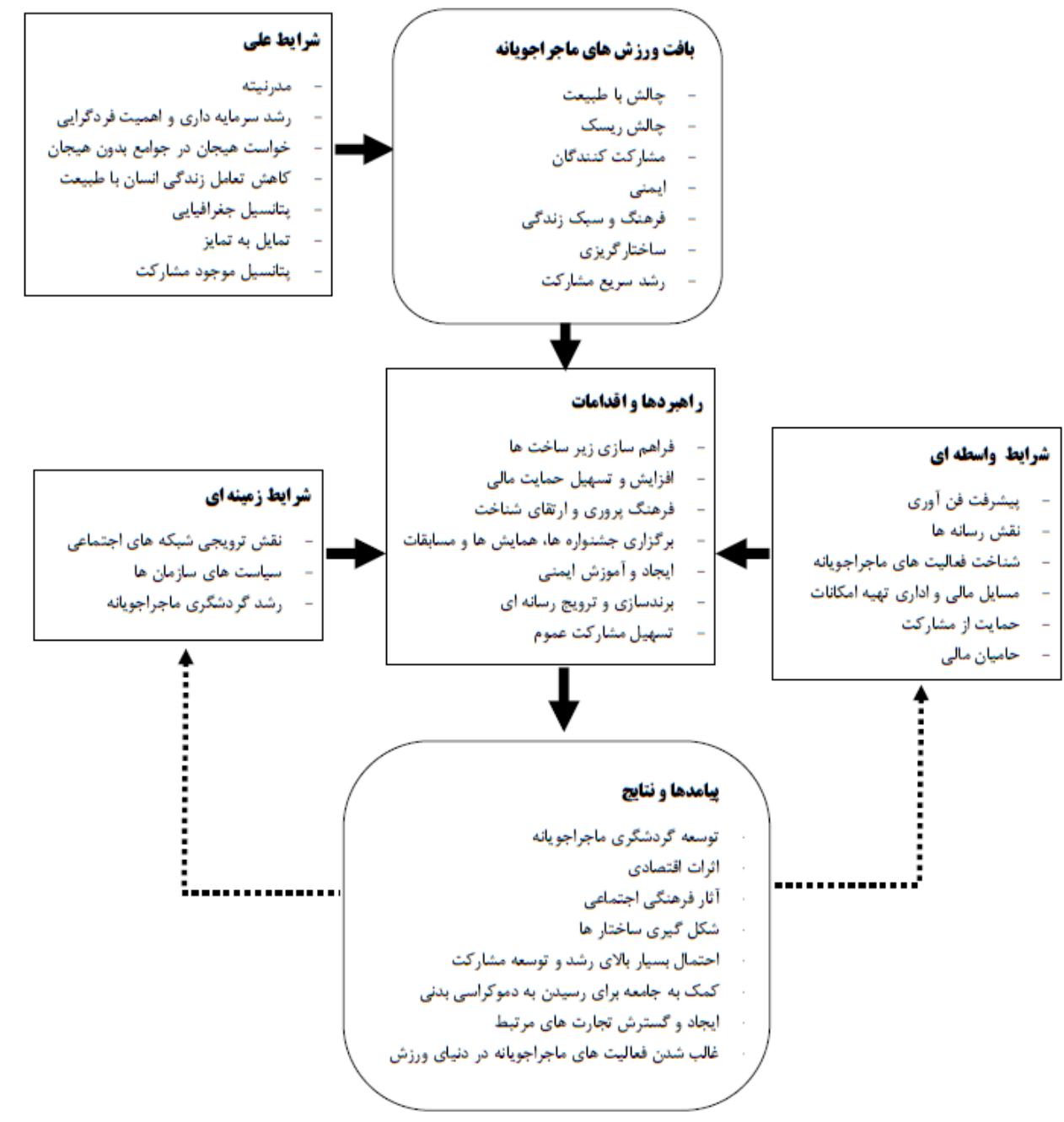

شكل ا. الكوى توسعه ورزشهاى ماجر اجويانه

\section{بحث و نتيجه تيرى}

نقش ورزش هاى ماجر اجويانه در ورزش در سالهاى اخير روز به روز ير رنختر شده است. گستردكى و تنوع حوزه ورزشهاى ماجراجويانه به كونهاى است كه افراد با انخَيزه هاى (شناختى، روانى، زيستى و اجتماعى) مختلف مشاركت در فعاليت ورزشى مى توانند فعاليت دلخواه و مناسب خود را در اين حوزه بيدا كرده و به آن بيردازند (1)(1). با توجه به افزايش رو به رشد اختصاص زمان و توجه در بازار و رسانه به اين ورزشها توجه بسيار زيادى هم از طرف صاحبنظران آكادميك و غير آكادميك به اين فعاليتها جلب شده است. اين افزايش به حدى بالا بوده است كه برخى صاحبنظران مانند رينهارت ( (....) ورزشهاى ماجر اجويانه را ورزشهاى جايخزين مى نامند و بيان مىكند كه از لحاظ ايدئولوزيك و نيز در عمل جايكزينهايى براى ورزشهاى مرسوم و ارزشهاى مرسوم ورزشى ارائه مىكند(19) و به نظر مىرسد فرايند جايخزينى آغاز شده باشد. برخى 
Adventure sports development pattern (2017), Ch. Majidi, M, Saffari, Alireza Elahi, Mohammad Khabiri. Research in Sport Management \& Motor Behavior, In Press.

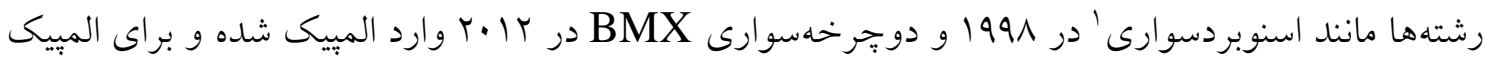
• • r.r. رشتهاى صخره نوردى، اسكيت و موجسوارى براى اضافه شدن به ورزشهاى المييكى مطرح شده اند. برويك (•l·(T) نيز بيان مى كند كه اين ورزشها ايدهاى كليدى جوامع مدرن را نمايش مىدهند و انتظار مى رود كه در آينده به رشد خود ادامه داده و تقسيمبندىهاى بيشترى به خود بخيرد و اينكه تئورىهاى بسيارى

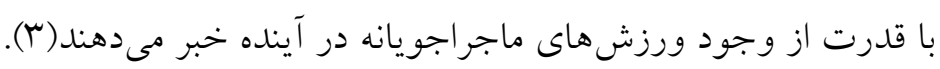
از اين رو با توجه به اهميت اين حوزه از فعاليتهاى ورزشى و تفريحى اين تحقيق قصد تدوين الكوى توسعه ورزش هاى ماجراجويانه را داشت. اين الكو كه هدف اصلى اين يزوهش بوده است را مىتوانيد در شكل 1 مشاهده كنيد. قابل ذكر است كه برخى از مقوله هاى ارائه شده در اين الخو ماهيتى عام داشته و مربوط به ذات فعاليتهاى ورزشى و تفريحى ماجراجويانه مى شود و برخى نيز به واسطه انجام اين بزوهش در ايران محدود به شرايط محيط اين كشور مىباشد. با توجه به اينكه ايران كشورى در حال توسعه و در حال تجربه روندهايى مشابه كشورهاى توسعه يافته در كذشته اما با سرعتى متفاوت مىباشد، مساله فراهم بودن زيرساخت در توسعه يد يدههاى مختلف مى تواند بسيار تاثير كذار باشد. اما فراهم سازى زير ساختها با توجه به ويز كى هاى متفاوت خرده فرهنگ حاكم در اين رشتهها و مشاركت كنند گان فعال و بالقوه مانند ساختاركريزى، اهميت به سبكهاى شخصى و خلاقيت و لذت گرايى؛ بايد به كونهاى باشد كه استقلال اين رشتهها حفظ شود و حداقل رسمى سازى ممكن را داشته باشد.

از دلايل شكل گيرى و توسعه فعاليتهاى ورزشى ماجراجويانه، همانطور كه در الكو نيز ارائه شده است، مدرنيته، سرمايهدارى و كاهش تعامل انسان با محيط طبيعى در جوامع مدرن است. همانطور كه كشمور ( (..... اشاره مى كند، ورزش وقتى اهميت بيدا مى كند كه ارضاء نيازهاى عميق انسان در جامعه فرا كنترل شده مدرن سخت است(IV). جوامع جديد متمركز بر كنترل و روزمركى، متمدن نمودن شكل زندكى و امن نمودن آن دارند. اما اين شرايط خلاءهايى در زندگى انسانى كه در طول تاريخ با جالش و خطر متعامل بوده است ايجاد مى كند. ورزش و به طور خاص ورزشهاى ماجراجويانه مىتوانند اين نيازهاى به شانس، رقابت و خطر (ريسك) را برآورده سازند. از طرفى بتانسيل مشاركت در فعاليتهاى ماجراجويانه در يكى منطقه جغرافيايى را مى توان به مشاركت كنند گان داخلى و خارجى (كردشخران) تقسيم نمود. در صورت تناسب علايق و تمايلات مشاركت افراد با جغرافياى فراهم فعاليتهاى ماجراجويانه مورد نظر از عوامل اصلى شكل گيرى مشاركت در فعاليتهاى ماجر اجويانه در نقاط مختلف مىباشند.

\footnotetext{
${ }^{1}$ Snowboarding
} 
Adventure sports development pattern (2017), Ch. Majidi, M, Saffari, Alireza Elahi, Mohammad Khabiri. Research in Sport Management \& Motor Behavior, In Press.

عدم تمايل به ساختارمندى يكى از مولفههاى مهم اين شيوه از يرداختن به فعاليت ورزشى و يا به بيان ويتن

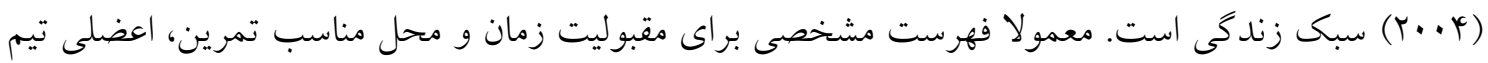
و مربى ندارند. فعاليتها بيشتر با مفعوم بازى هم معنى مىباشد و عموما جيزى به نام مربى معنى ندارد (ه). با توجه به اينكه جالش با طبيعت در اكثريت فعاليتهاى ماجر اجويانه وجود دارد و از طرفى ويزگى هاى مشاركت كنندگان را مىتوان در مواردى مانند ريسكيذيرى، تمرينات و اجراى منطقى و مسئولانه، تلاش در انجام كارهاى درست، استفاده از استعدادهاى تا نهايت قابليت توانايى هاى يك فرد، سرگرم كردن ديخران، جلب رضايت بركزاركنندكان و انتظارات تماشاكران، و حتى رياضت و زهد ديد (ه)؛ مىتوان كفت مولفه ريسك از مهم ترين اجزاى فعاليتهاى ماجراجويانه است. اما ريسك موجود در فعاليتهاى ماجراجويانه نسبى بوده و ادراك آن در ميان افراد (·r). و جوامع (Y) مختلف متفاوت است. لازم به ذكر است كه ورزشكاران ماجر اجو با آكاهى بر آسيب هاى احتمالى و نكات ايمنى و آماده سازى طولانى مبادرت به فعاليتها مى كنند اما نمايش هاى معمولاً كو تاه رسانهاى و به اشتراى كذارى حوادث اين فعاليتها در شبكه هاى اجتماعى، باعث ايجاد كليشه خطرناك بودن اين فعاليتها و غير عقلانى بودن برداختن به آنها شده است. از اين رو براى اصلاح نخرش هاى نادرست كه منجر به عدم حمايت و يا تمايل در مشاركت مىشود و يا ادراكات ناصحيح از مولفههاى صلاحيت لازم و ريسك موجود در فعاليتها، ارتقاى شناخت و آموزش نقش بسيار مهمى را ايفا مى كند. از حوزههاى بسيار مرتبط با فعاليتهاى ماجراجويانه، گردشخرى ماجراجويانه است كه در سالهاى اخير همواره در حال رشد بوده است. ارزش بازار كردشخرى ماجراجويانه به صورت تقريبى بعץ ميليارد دلار آمريكا تخمين زده شده است كه انتظار مىرود به طور مداوم در سراسر دنيا رشد يابد (Yr). قابل ذكر است رشد سريع اين حوزه و در كل فعاليتهاى ماجراجويانه به صورت قابل توجهى تحت تاثير كسترش به اشتراى كذارى تجارب مشاركت در فعاليتهاى ماجراجويانه مختلف در شبكه هاى اجتماعى بوده است كه كاهى به صورت يكى كنش فردى و كاهى به صورت برنامه ترويجى مدوّن تحت حمايت حاميان مالى و ارائه دهندكان خدمات كردشخرى ماجراجويانه مىباشد. به نظر مىرسد دو حوزه فعاليتهاى ورزشى ماجراجويانه و خردشخرى ماجر اجويانه مى توانند تاثير متقابل مثبى بر روى هم داشته باشند.

فن آورى نيز به نوبه خود باعث بيشرفت و تغييرات فعاليتهاى ماجر اجويانه شده است به عنوان مثال طراحى و ساخت تخته هاى موج سوارى جديد در جّكونكى تكنيك هاى ورزشكاران تاثير بسيار كذاشته و به آنها اجازه رد كردن مرزهايى از كذشته را داده است. طراحى كفشهاى دويدن، دوجرخه ها، قايقها، اسنوبردها و از اين قبيل نيز همين گونه است (ه). البته بيشرفت فن آورىها به دنبال خود لزوم تقبل هزينههاى مالى را براى

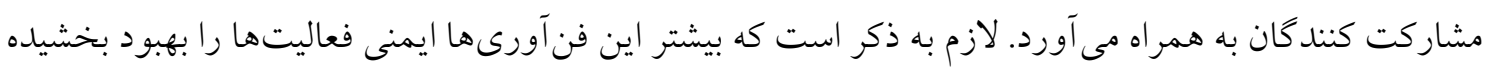
و محدوديت ها را مى كاهد. اينجاست كه حضور حمايتهاى مالى و ادارى براى تسهيل دسترسى افراد به 
Adventure sports development pattern (2017), Ch. Majidi, M, Saffari, Alireza Elahi, Mohammad Khabiri. Research in Sport Management \& Motor Behavior, In Press.

امكانات به شكل قابل توجهى نمايان مى شود. جر اكه همانكونه كه سهولت دسترسى مىتواند عاملى انخيزشى براى مشاركت باشد، عدم دسترسى آسان عاملى بازدارنده خواهد بوده.

راهبردها و اقدامات لازم براى توسعه ورزش هاى ماجر اجويانه كه در الكو حاصل شده است شامل فراهم سازى زيرساختها؛ افزايش و تسهيل حمايت مالى؛ فرهنگ يرورى و ارتقاى شناخت؛ بركزارى جشنوارهها، همايشها و مسابقات؛ ايجادو آموزش ايمنى؛ برندسازى و ترويج رسانهاى؛ و تسهيل مشاركت عموم مىباشد. براى عملى نمودن اين راهبردها بايد نكاتى را مد نظر قرار داد. همانطور كه مقولههاى بخش ييامدها در الكَى ارائه شده در اين تحقيق نيز نشان مىدهد اقدام براى فراهم نمودن زيرساختهاى لازم، توسعه مشاركت و بركزارى رويدادها و از اين قبيل فعاليتها با خود شكل گيرى ساختارها، بروكراسى و مسايل ادارى را به همراه خواهد

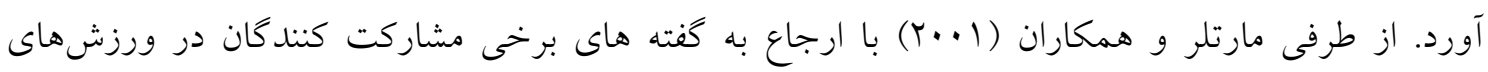
ماجراجويانه بيان مى كنند كه با شروع دخالت مسئولين، مربيان، مديران سازمانى، حاميان مالى و اهل رسانه و وقتى آنها فشار رقابت و برد و باخت را وارد مى كنند، ماهيت و اصالت اصلى اين فعاليتهاى ورزشى شروع به نايديد شدن مى كند(سT). اطلاعات به دست آمده در اين تحقيق نيز با اين اظهارات همراستا بود. از اين رو لازم است براى اطمينان از اينكه اين اقدامات با تلاش براى كمك، باعث از بين بردن ماهيت فعاليتها نمىشود، كمترين دخالت در شيوه هاى اجرا و كمترين ميزان رسميت ايجاد كردد. تسهيل حمايت مالى نيز به وسيله انعطاف يذير نمودن قوانين و مقررات و حتى تشويقهاى مالياتى مىتواند باعث افزايش حمايت از بركزارى

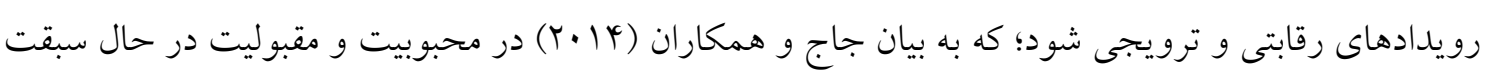

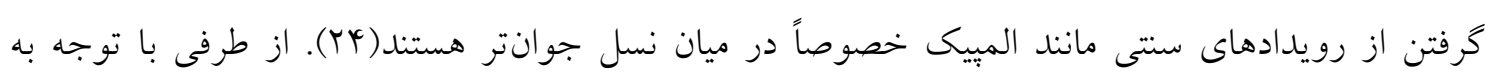

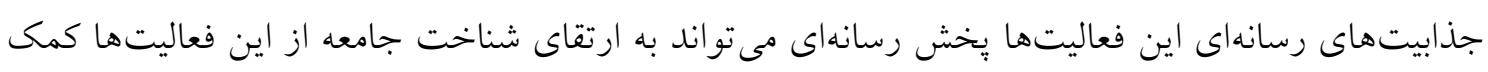
نمايد. همجنين افزايش شناخت صحيح از طريق آموزش و اطلاع رسانى مىتواند علاوه بر اينكه تمايل به مشاركت در ورزش هاى ماجراجويانه را افزايش دهد باعث نزديكى نمودن ادراكات افراد از دو مولفه قابليتهاى مهارتى خود و ريسكهاى موجود در فعاليتها شود كه نتيجه آن مشاركت هاى موفق ماجر اجويانه و جلو كيرى از حوادث و اتفاقات ناخوشايند خواهد شدر.

به جهت بحث در خصوص ييامدها و نتايج حاصل از توسعه فعاليتهاى ورزشى ماجر اجويانه مىتوان اشاره نمود كه روند افزايشى و رو به رشد مشاركت در فعاليتهاى ماجراجويانه در حال ادامه است (Tه). شايد به

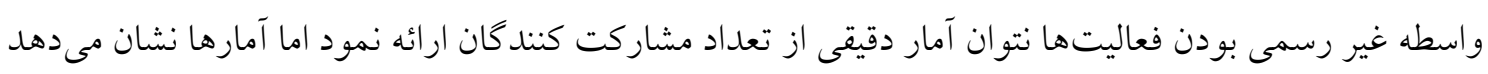
كه يك سوم از فروش محصولات ورزشى معادل عا ميليارد دلار مربوط به ورزش هاى ماجر اجويانه مىشوند

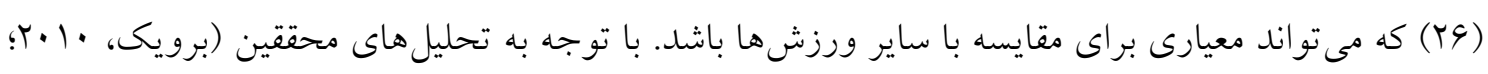

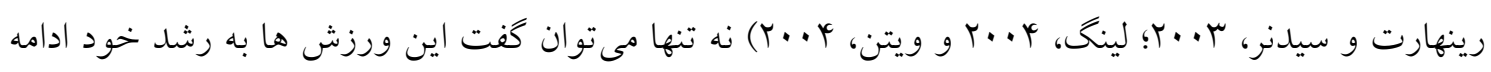


Adventure sports development pattern (2017), Ch. Majidi, M, Saffari, Alireza Elahi, Mohammad Khabiri. Research in Sport Management \& Motor Behavior, In Press.

خواهند داد بلكه مىتوان انتظار داشت كه جايكزين بسيارى از فعاليتهاى ورزشى مرسوم گردند(آ، ه، 9، 9). اما در حال حاضر با توجه به اينكه انخيزهها و تمايلات همه افر اد جامعه براى مشاركت در فعاليت بدنى يكسان نمى باشد و براى رسيدن به دموكراسى بدنى بايد به انخيزهها و تمايلات همه بخشهاى جامعه اهميت داده و شرايط مشاركت آنها را فراهم آورد؛ بايد توجه داشت كه در نمودار توزيع جمعيت نرمال به طور تقريب مىتوان

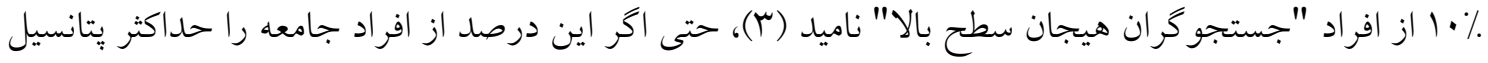
مشاركت در ورزش هاى ماجر اجويانه بناميم (كه اينخونه نيست)، لزوم توجه به اين بخش از جوامع نيز به خوبى قابل درى خواهد بود. بخش ديخرى از يتانسيل مشاركت گردشخران هستند و با توسعه گردشكرى ماجر اجويانه علاوه بر تاثير قابل توجه بر توسعه مشاركت در فعاليتهاى ماجر اجويانه، اثرات اقتصادى قابل توجهى را به

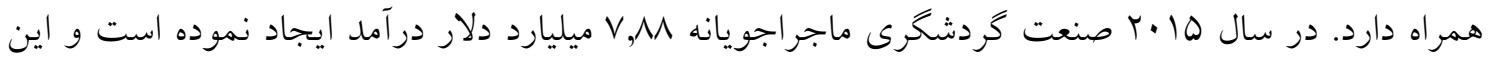
روند رو به رشد مىباشد. تحليل هاى بازار جهانى گردشخرى' خبر از رسيدن نرخ رشد مركب سالانه广

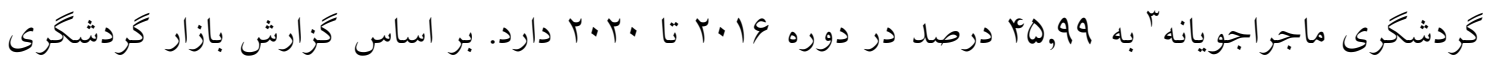
ماجراجويانه، افزايش ترجيح ماجراجويى بر ساير انواع گردشخرى محرك اصلى رشد بازار خواهد بود (YV). از اين رو براى منتفع شدن از مزاياى يتانسيل هاى صنعت گردشخرى لازم است تا به اين بخش از گردشخرى به طور جدى توجه شود. يزوهش حاضر با محدوديتهايى ماند عدم دسترسى به اطلاعات مربوط به وضعيت كنونى فعاليتهاى ماجر اجويانه، مسايل قانونى مرتبط و فروش تجهيزات مورد نياز فعاليتهاى ماجراجويانه كه مىتواند معيارى براى شناسايى ميزان مشاركت باشد، روبرو بود. از اين رو ييشنهاد مىشود در مطالعات آينده، ميزان و انخيزههاى مشاركت، مسايل قانونى، مطالعه وضعيت موجود و آينده يزوهى مورد توجه قرار گيرد. همانطور كه در الكو (شكل () نيز قابل مشاهده مى باشد، بيامدها و نتايج حاصل از راهبردها و اقدامات در جهت توسعه فعاليتهاى ورزشى ماجراجويانه بر شرايط واسطهاى و زمينهاى تاثير مى گذارد. از اين رو لازم است قبل از هدف گزينى

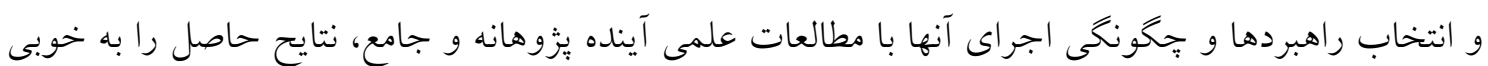
بررسى نموده تا علاوه بر بهرهمندى از مزاياى اين حوزه از ورزش، از صدمه زدن به آن و آسيبهاى احتمالى جلو گيرى نمود. از اين رو بيشنهاد مى شود به جهت شناخت و برخورد مناسب با حوزه ورزش هاى ماجر اجويانه كه به احتمال زياد در آينده به يكى از بخش هاى اصلى ورزش تبديل خواهد شد، يُزوهش هاى علمى بيشترى خصوصاً با رويكرد آينده يزوهى صورت كيرد.

\footnotetext{
${ }^{1}$ Global adventure tourism market

${ }^{2}$ Compound Annual Growth Rate (CAGR)

${ }^{3}$ Adventure tourism market report
} 
Adventure sports development pattern (2017), Ch. Majidi, M, Saffari, Alireza Elahi, Mohammad Khabiri. Research in Sport Management \& Motor Behavior, In Press.

\section{منابع}

1. Gáldi, G., 2012. Christodoulides Efstathios (Doctoral dissertation, Semmelweis University).

2. Hajkowicz, S.A., Cook, H., Wilhelmseder, L. and Boughen, N., 2013. The Future of Australian Sport: Megatrends shaping the sports sector over coming decades. A Consultancy Report for the Australian Sports Commission.

3. Breivik, G., 2010. Trends in adventure sports in a post-modern society. Sport in Society, 13(2), pp.260-273.

4. Beal, B., 1999. Skateboarding: an alternative to mainstream sports. Inside sports., pp.139-145.

5. Rinehart, R.E. and Sydnor, S., 2003. To the Extreme: Alternative Sports, Inside and Out. SUNY Press.

6. Wheaton, B. ed., 2004. Understanding lifestyle sport: Consumption, identity and difference. Routledge.

7. Wheaton, B., 2000. "Just do it": Consumption, commitment, and identity in the windsurfing subculture. Sociology of Sport Journal, 17(3), pp.254-274.

8. Midol, N. and Broyer, G., 1995. Toward an anthropological analysis of new sport cultures: The case of whiz sports in France. Sociology of Sport Journal, 12(2), pp.204-212.

9. Lyng, S. ed., 2004. Edgework: The sociology of risk-taking. Routledge.

10. Robinson, V., 2008. Everyday masculinities and extreme sport: Male identity and rock climbing. Berg.

11. Alosi, M., 2007. The Evolution of the Social Functions of Sports \& the Advent of Extreme Sports.

12. Ellmer, E. and Rynne, S., 2016. Learning in action and adventure sports. AsiaPacific Journal of Health, Sport and Physical Education, 7(2), pp.107-119.

13. Pike, E.C. and Beames, S., 2013. Outdoor adventure and social theory. Routledge.

14. Corbin, J. and Strauss, A., 2008. Basics of qualitative research: Techniques and procedures for developing grounded theory.

15. Glaser, B.G., 1992. Basics of grounded theory analysis: Emergence vs forcing. Sociology Press.

16. Norbert, E. and Dunning, E., 1986. Quest for excitement: sport and leisure in the civilizing process.

17. Cashmore, Ellis, 2000, Making sense of sports. Routledge, Ed.3.

18. Almeida, M.A.B.D. and Gutierrez, G., 2013. Norbert Elias and contemporary sport: comment about the civilising process and controlling emotions in extreme 
Adventure sports development pattern (2017), Ch. Majidi, M, Saffari, Alireza Elahi, Mohammad Khabiri. Research in Sport Management \& Motor Behavior, In Press.

sports. Revista da Associação Latino-Americana de Estudos Sócio-culturais do Esporte (ALESDE), 3(2), pp.46-57.

19. Rinehart, R., 2000. Emerging arriving sports. Alternatives to formal sports Handbook of Sports Studies (pp. 504-519).

20. Zuckerman, M. and Kuhlman, D.M., 2000. Personality and risk-taking: common bisocial factors. Journal of personality, 68(6), pp.999-1029.

21. Buckley, R., McDonald, K., Duan, L., Sun, L. and Chen, L.X., 2014. Chinese model for mass adventure tourism. Tourism management, 44, pp.5-13.

22. Adventure Travel Trade Association, Adventure tourism market study, August 2013, Retrieved from http://files.adventuretravel.biz/docs/research/adventuretourism-market-study-2013-web.pdf.

23. De Martelaer, K., De Knop, P. and Buisman, A., 2001. 15 CHILD-ORIENTED SPORT. Values and Norms in Sport: Critical Reflections on the Position and Meanings of Sport in Society, p.303.

24. Judge, L., Lee, D., Petersen, J., Bellar, D., Surber, K. and Krill, C., 2014. The impact of social media on the awareness of the Olympic movement. The Sport Journal, 17.

25. Ostrowski, J., 2002. Corporate America makes pitchmen of pariahs. Street \& Smith's Sports Business Journal, pp.12-18.

26. Liberman, N., 2004. New heights or a crash landing. Street \& Smith's Sports Business Journal, 25, pp.12-18.

27. Adventure Tourism Market Growing at Nearly 46\% CAGR to 2020, 2016 October 14). Retrieved from http://www.prnewswire.com/news-releases/ adventuretourism-market-growing-at-nearly-46-cagr-to-2020-597059331.html.

28. Priest, S. and Martin, P., 1985. The Adventure Experience Paradigm. 
Adventure sports development pattern (2017), Ch. Majidi, M, Saffari, Alireza Elahi, Mohammad Khabiri. Research in Sport Management \& Motor Behavior, In Press.

\section{Adventure Sports Development Paradigm}

1- Chalak Majidi, 2- Marjan Saffari, 3- Alireza Elahi, 4- Mohammad Khabiri

1- Sport management Ph.D Student, Kharazmi University

2- Assistant Professor, Tarbiat Modares University

3- Associate Professor, Kharazmi University

4- Associate professor, University of Tehran

\section{Abstract:}

In the recent years, adventure sports has been growing increasingly. Adventure sports are new and appealing activities that regularly include some kinds of physical and mental challenges and relative presence of natural environment. These activities are presenting new paths and sometime they called as a serious competitor for mainstream sport. The aim of this study was to present a paradigm for adventure sports development. The qualitative methodology used in this study has followed an interpretive approach that was achieved by grounded theory. Data was collected from literature, interviews, focus groups, adventure sports related documentary films and movies. Results of this study are presenting adventure sports paradigm. In this paradigm developmental causal conditions of adventure sports, contexture of adventure sports, existing intervening conditions and contextual conditions, strategies and tactics for developing adventure sports and finally consequences. To appropriate recognition and encountering with this field, that most probably will be one of the main part of sport, we suggest doing more scientific research, especially with futurology approaches.

Keywords: Paradigm, Adventure Sports, Qualitative research, Grounded Theory 